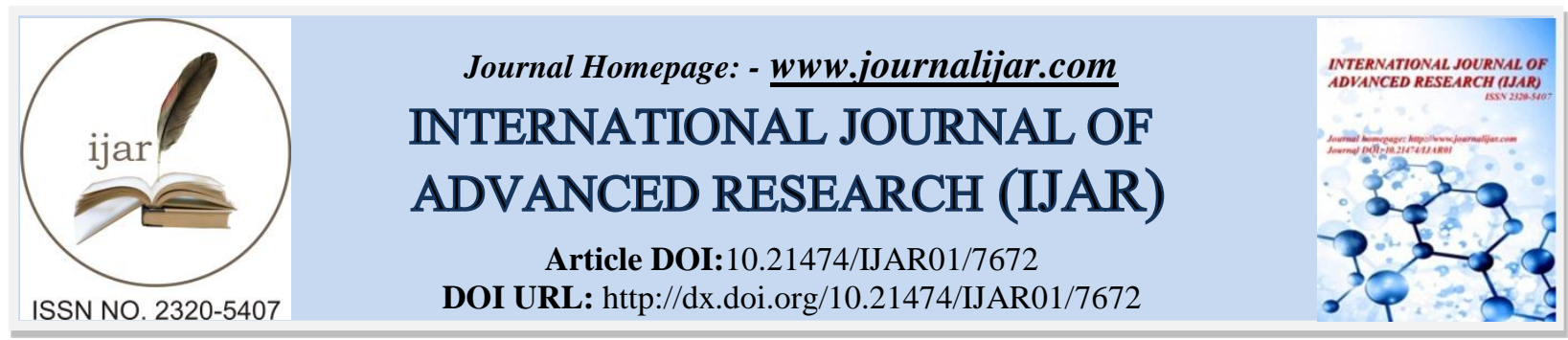

RESEARCH ARTICLE

\title{
GRASSROOTS WOMEN POLITICAL PARTICIPATION AND POVERTY REDUCTION STRATEGIES IN GHANA AND NIGERIA.
}

Ngozi Nwogwugwu' ${ }^{1}$ and Busola Odedina ${ }^{2}$.

1. Ngozi Nwogwugwu, PhD, is a Senior Lecturer in the Department of Political Science and Public

Administration, Veronica Adeleke School of Social Sciences, Babcock University, Ilishan-Remo, Ogun State, Nigeria.

2. Busola Odedina is a PhD student in the Department of Political Science and Public Administration, Veronica Adeleke School of Social Sciences, Babcock University, Ilishan-Remo, Ogun State, Nigeria.

\section{Manuscript Info}

Manuscript History

Received: 05 July 2018

Final Accepted: 07 August 2018

Published: September 2018

Keywords:-

Grassroots women, political participation, poverty reduction strategies, Ghana, Nigeria.

\section{Abstract}

The practice of representative democracy across Africa for close to two decades without interruption had not translated to reduction of the level of poverty for the world's poorest continent. Over the last decade, there had been increase in the level of participation in the political process by grassroots women, especially in Ghana and Nigeria. Does active participation of grassroots women in the political process translate to formulation and implementation of viable poverty reduction programmes by elected officials? The study examined the effect of grassroots women political participation on poverty reduction in two African countries; Ghana and Nigeria. The study adopted descriptive survey design utilizing both quantitative and qualitative data. Quantitative data was collected from 500 respondents (250 respondents) from each country using multistage sampling technique. The response rate was $87.4 \%$. Data were analyzed using descriptive statistics while hypotheses were tested using regression. Grassroots women political participation had significant effect on poverty reduction in Ghana $\left(\beta=.167, t(240)=2.600, R^{2}=0.28, p<0.05\right)$, and in Nigeria $\left(\beta=.082, t(197)=1.145, R^{2}=0.07, p<0.05\right)$. Grassroots women organizations need to critically appraise new strategies that would facilitate getting more women into decision making roles.

Copy Right, IJAR, 2018,. All rights reserved.

\section{Introduction:-}

Women political participation and involvement in decision making roles has been in the front burner of political discourse for some decades. However, in spite of the adoption of the affirmative action policy of $35 \%$ female representation at the national legislative bodies, only view countries in Africa such as Rwanda, South Africa, Mozambique have met the target, while most of Africa suffer several restrictions attributable to culture, religious beliefs, tradition and lack of legal and institutional framework (Cole 2011). In spite of the many resolutions, conventions, statutes adopted with a view to achieving greater women participation in politics and decision making roles, at the global, regional and national levels, "women are still substantially under-represented in politics in most countries of the world. They form a small minority of parliamentarians world-wide, although the current world

Corresponding Author :- Ngozi Nwogwugwu.

Address:- Ngozi Nwogwugwu, PhD, is a Senior Lecturer in the Department of Political Science and

Public Administration, Veronica Adeleke School of Social Sciences, Babcock University, Ilishan-Remo, 
average of $19.2 \%$ is the highest proportion ever recorded" (Inter-Parliamentary Union 2010 cited in Pogoson 2015 , p. 76).

None of the countries in West Africa (including Ghana and Nigeria) have been able to exceed even the $10 \%$ level in terms of elected representatives in the legislative bodies, though belated attempts have been made to augment with appointed officials. The need for active participation of all segments of the society in the political process and decision making process in order for democracy to consolidate and ensure inclusiveness in governance processes cannot be over-emphasized. A governance and decision making process that ignores about half of the population cannot be regarded as inclusive or developmental.

As Madeline Albright, former Secretary of State of the United States aptly stated, "If democracy is going to put down strong and healthy roots, it must profit from all the full and equitable participation of women in national and local leadership positions and in a full range of advocacy roles" (National Democratic Institute, 2010). Although international searchlight had been beamed on women political participation at the national level, with the belief that it would orchestrate to the lower levels, Albrights position highlights the imperative of gender equality in political participation at all levels of governance. This is orchestrated by Huq (2016) who writes that the goals of equality, development and peace are not achievable without the active participation of women at all levels of decision making including the grassroots.

Ghana and Nigeria which are regarded as the largest economies and democracies in Anglo-Phone in West Africa are among the poor countries of the world. Most of the poor in the two countries are those who reside at the grassroots level including those in the rural areas, with a larger proportion being women who survive on subsistence farming. Although the proportion of Ghana's population believed to be living below the one dollar/day benchmark had decreased progressively from $51.7 \%$ in $1991 / 92$ to less than $30 \%$, a lot of work still needs to be done to completely eradicate poverty in the country (International Monetary Fund 2012).

Nkum and Ghartey (2000) write that poverty levels and dimensions in Ghana vary from rural to urban people, as well as between men and women. Whereas rural dwellers view poverty from the perspective of lack of food, insecurity, and inability to active contribute towards and participate in social activities, the urban dwellers on the other hand see poverty as from the prism of unemployment, lack of access or inadequate social services, lack of access to capital for investment purposes and lack of skills acquisition training that would impede ability to meaningful living (Baoteng, Boateng and Bampoe 2015; Nkum \& Ghartey,2000).

The implementation of Ghana's Poverty Reduction Strategy Policy over the last two decades had resulted in the reduction in the number of people who live below the poverty level. "However, poverty is still high in Ghana and remains one of the major hindrances to Sustainable development in the country" (Domfeh, Ahenkan, and BawoleIs, 2012, p. 307).

Poverty in Nigeria is equally multi-dimensional and deeply rooted, in spite of the fact that the country possesses enormous resources with the capacity to completely eradicate poverty. It has political, economic and cultural factors that has structured it to negatively affect women more than men. As a consequence, more women in Nigeria are regarded as living in poverty than men. "Poverty has a woman face since $70 \%$ of people in poverty are women. This is a challenge to sustainable development" (Fapohunda, 2012, p. 15).

Over the last four decades, Nigeria had implemented several poverty reduction/alleviation programmes, such as Operation Feed the Nation (OFN), launched in the 1970s and Green Revolution in 1980. Others include, the Directorate of Food, Roads and Rural Infrastructure (DFFRI), National Directorate of employment (NDE), Better Life Programme, (BLP), the Peoples' Bank of Nigeria (PBN), Family Support programme (FSP), Family Economic Advancement Programme (FEAP), National Poverty Eradication Programmes (NAPEP), and National Economic Empowerment and Development Strategy (NEEDs) (Anger 2010).

The limited involvement of the female gender in the decision making processes at the grassroots level, especially in the design and implementation of poverty reduction programmes targeting them has negative implications for the two countries as evidenced by the failure of the top-down programmes that failed to meet the needs of the target population. This had made poverty reduction among the large population of women at the grassroots level of Ghana and Nigeria a tall order. The study therefore investigated grassroots women political participation in the decision 
making and implementation of poverty reduction programmes in Ghana and Nigeria. The study is segmented into introduction, literature review, theoretical framework, methodology, findings and discussions, the way forward and conclusion.

\section{Women participation in decision making, empowerment and poverty reduction across Africa} Isshaku (2012) write that empowerment of the community members is necessary in order for them to be able to actively participate in the policy making process. This would include ensuring that community members especially those who at the grassroots level have access to resources which would include; adequate funding, government capacity building programmes, education, leaders, and volunteers to support initiatives. Among the areas where involvement of community members is needed in both Ghana and Nigeria is in the area of poverty reduction strategies as a large part of the poor in both countries are reported to live and operate at the grassroots level.

Okafor and Akokuwebe (2015), write that as a result of the fact that almost 50\% of the population of Africa are female, reducing extreme poverty and economic empowerment of women is a vital part of any sustainable effort at eliminating poverty across Africa. This could be done by putting in place the enabling laws and policies that ensure that there is equal access of both gender to critical resources. Such efforts would include ensuring gender equitable access to capital and large-scale investment as well as land ownership practices that discriminate against women.

Identified among the major institutional handicaps in Ghana that retards poverty reduction are the system of land ownership, land management and administration as well as the structure of governance. Kessey (2013, p. 081) writes that the "system of land ownership especially in the Akan areas of Ghana is not pro-poor This is confirmed by the high 'token fees' for drink, one has to pay to the traditional land owners before access to land is granted for whatever purpose".

Land ownership is of critical importance in African countries as a majority of those who live in the grassroots survive on subsistence farming, implying that access to land becomes the determining factor for overcoming poverty. Women's land rights have become contentious as there is direct relationship between having access to land for farming purposes, ownership of land, and overcoming poverty. The disconnect in efforts at poverty reduction can be appreciated when viewed from the perspective that women are reported to contribute more than $80 \%$ of the food that is produced in Africa, whereas they own only 1\% of the land (SOFA, 2011 cited in Odeny 2013).

"Poverty reduction initiatives that use the community as the main channel for mobilization and involvement must focus on the dynamics and the specificity of context as different kinds of participation imply significantly different levels of engagement" (Osei-Kufuor and Koomson, 2014, p. 1626).

Isshaku (2012) writes that challenges of Grassroots Participation in Local Governance has increasingly exposed policy makers to the need for them to get grassroots dwellers to become more involved in the policy-making process. Such community members' involvement should not end with only the male members of such communities, there must be effort to ensure that more decision making roles are allocated for women to increase the population of women in decision making positions. It is getting more women involved in the decision making roles that led to the adoption of poverty reduction strategies that the interests of the women can be adequately catered for.

Kasomo (2012) writes that in Kenya, political development had been perceived from a sexist perspective. As such women have no significant input in the political dispensation. In this regard, the oppression of women and their subordinate positions are thus located in the personal, structural and cultural factors. Pertaining to personal factors, the paucity of women is attributed to psycho-social attributes which entail their personality, attitudes and behavioral skills. Kasomo (2012) stated that the concentration of women decreases with the increase of the level of the job group. The higher the job group, the fewer the women who occupy it. In that case, only a small percentage of women compared to men are in key positions to make and influence decisions in public service. The low number of women in key decision making roles in Kenya, most of the other African countries is evidence of lack of poverty reduction strategies specifically targeting women at the grassroots level in such countries.

\section{Theoretical Framework}

Intersectionality Theory

The study adopts intersectionality theory as its theoretical construct. Intersectionality was first coined by black feminist legal scholar and critical race theorist Kimberle W. Crenshaw (1989) in the late 1980s. Other scholars that 
have expounded on intersectionality theory include McCall (2005, 2001) and Hancock (2007). Intersectionality is "an analytic frame that disrupted the tendency in social justice movements and critical theorizing to treat race and gender as mutually exclusive categories of experience and analysis (Crenshaw 1989)" (Cooper 2016, p. 385). Intersectionality theory interrogates the relationship between gender, race/ethnicity, class and sexuality in analyzing the experiences of women, especially black women and women of colour (Latina women). The proposition of the theory is that the interest of women cannot be adequately captured in the policy process through single analytical framework of class, race or gender. According to Walby, Armstrong and Strid (2012):

Groups at the intersection of two or more identity categories are left out of focus in both analysis and politics: Black women, ethnic minority women, or 'women of colour', groups positioned at the intersection of gender and race/ethnicity, become marginalized as a group and 'face limited options of political communities formed either around ethnicity or around gender, rather than political action that engages with the particular difficulties at the intersection' (p. 226)

Crenshaw (1991, p. 1245) stated that intersectionality demonstrated "the need to account for multiple grounds of identity when considering how social world is constructed". It is in furtherance of this perspective that she posited the relationship between structural intersectionality and political intersectionality. "Structural intersectionality referred to a convergence of 'race, gender, and class domination' wherein social interventions designed to ameliorate the results of only racism, or sexism, or poverty would be insufficient to address the needs of a woman of color marginalized by the interaction of all three systems of power" (Crenshaw 1991 cited in Cooper, p. 386). According to Crenshaw (1991) political intersectionality on its part seeks to "highlight that women of color are situated within at least two subordinated groups that frequently pursue conflicting political agendas" (p. 1252).

Crenshaw (1991, 1989) postulated that the experiences of black women and women of color required new paradigms in feminist theorizing as existing feminist theories could not adequately capture them. Intersectionality in Crenshaw's view "created an analytic framework that exposed through the use of powerful metaphor exactly what it meant for systems of power to be interactive, and explicitly tying the political aims of an inclusive democracy to a theory and account of power" (Cooper, 2016, p. 386).

McCall (2005) in her contribution on intersectionality identifies three distinct approaches: intra-categorical, anticategorical, and inter-categorical (1773-4). The intra-categorical approach to intersectionality "is concerned to 'focus on particular social groups at neglected points of intersection' 'in order to reveal the complexity of lived experience within such groups'. This approach draws inspiration from Crenshaw's work in order to examine groups, often small ones, which had not been previously analysed" (Walby, Armstrong and Strid, 2012, p. 227). The anticategorical approach "considers the stabilization of categories to be problematic in essentializing and reifying the social relations that the analyst may be seeking to change. It thus prioritises fluidity over stability of categories". The third approach according to McGall (2005) "The inter-categorical approach 'provisionally adopt[s] existing analytical categories to document relationships of inequality among social groups and changing configurations of inequality among multiple and conflicting dimensions" (cited in Walby, Armstrong and Strid, 2012, p. 227). McCall (2005) preferred approach is the inter-categorical, as a result of its power in engaging with the larger structures that generate inequalities, a position that was greatly inspired by the propositions of Crenshaw (1991).

As a result of the elitist and male dominated nature of politics in Ghana and Nigeria, the formulation and implementation of poverty reduction strategies and programmes are not carried out with the unique needs of the women considered. Grassroots women are not involved in the design of these poverty reduction strategies, either in terms of making input or at the stage of decision of making. Poverty reduction strategies in the two West African countries are generalist in approach targeting just a class (the poor), this has negative implications for grassroots women who are affected by various factors just beyond that of class as proposed by the intersectionality theorists. Even when poverty reduction programmes are reported to be targeting women,(such as the Better Life for Rural Women) it only targeted the female gender and the class from and elite perspective without interrogating other vectors such as race/ethnicity and sexuality, which also had made such strategies defected in meeting the expected needs of the grassroots women. 


\section{Methodology:-}

The study adopted survey research design. The study areas were Ghana and Nigeria of the largest democracies in Anglo-phone West Africa. The population of the study were politicians, civil servants, members of civil society organizations, teachers, health practitioners, community leaders, leaders of women organizations and business persons from four selected cities, two from each of the two countries. Multi-stage sampling technique was adopted for the study. The first stage involved the purposive selection of Southern Ghana and Southern Nigeria being parts of the two countries that have high rate of women political participation in the country. As a result of religious factors, there is some level of limitation of women political participation in the Northern parts of the countries where the populations are predominantly Muslim. The second stage involved purposive selection of four cities Accra and Ho from Southern Ghana and Lagos and Owerri from Southern Nigeria because of high level of grassroots women political participation being recorded in the selected cities. The third stage involved the Stratified random sampling of 500 respondents ( 250 from each of the countries).

The researchers engaged in disproportionately sampling by ensuring that a larger number of the respondents were female even though the population figures indicate that women are almost half of the population of both countries. Validated questionnaire was the instrument of data collection. The researchers administered the questionnaire in the selected cities personally over a period of four months covering November 2017 - February 2018. Data were analyzed using descriptive and inferential (regression) statistics. The hypotheses were tested at $5 \%$ level of significance.

\section{Hypotheses:-}

$\mathrm{Ho}_{1}$ : Grassroots women political participation had no significant effect on poverty reduction in Ghana

$\mathrm{Ho}_{2}$ : Grassroots women political participation had no significant effect on poverty reduction in Nigeria

Findings and Discussions:-

Table 1:-Grassroot Women Political Participation

\begin{tabular}{|l|l|l|l|l|l|l|}
\hline & GHANA & \multicolumn{2}{l|}{ NIGERIA } \\
\hline Statements & M. & SD & V & M & SD & V \\
\hline $\begin{array}{l}\text { Large number of women are actively involved in the } \\
\text { political process }\end{array}$ & 2.21 & 1.094 & 1.197 & 3.84 & 0.863 & 0.746 \\
\hline $\begin{array}{l}\text { Most of the women who are active in politics are not } \\
\text { occupying any positions of authority }\end{array}$ & 3.84 & 0.869 & 0.756 & 3.78 & 0.856 & 0.733 \\
\hline $\begin{array}{l}\text { At the ward and local government/council levels, the } \\
\text { political party officials are mostly men }\end{array}$ & 4.07 & 0.863 & 0.928 & 4.13 & 1.032 & 1.064 \\
\hline $\begin{array}{l}\text { The women who are actively involved in the political } \\
\text { process are not involved in the making of policy decisions } \\
\text { at the grass roots level }\end{array}$ & 2.28 & 1.122 & 1.258 & 2.42 & 1.160 & 1.346 \\
\hline $\begin{array}{l}\text { Cultural factors such as attachment to family and } \\
\text { patriarchal nature of the society discourage women from } \\
\text { aspiring for key positions where they would be involved in } \\
\text { decision making }\end{array}$ & 3.96 & 1.044 & 1.091 & 3.99 & 0.950 & 0.903 \\
\hline
\end{tabular}

Source:Researchers field survey (2017-2018)

Table 1 above shows that on a scale of five, the respondents reported that large number of women were actively involved in the political process had $(\mathrm{M}=2.21, \mathrm{SD}=1.09)$ in Ghana, indicating that the number of women actively involved in the political process is low. The scores for Nigeria were $(M=3.84, S D=0.86)$ indicating a moderately high level of participation in the political process by women. Most of the women who are active in politics not occupying any positions of authority had score of $(\mathrm{M}=3.84, \mathrm{SD}=0.87)$ in Ghana and $(\mathrm{M}=3.78, \mathrm{SD}=0.86)$ in Nigeria, which implies that most of the women in both countries are not occupying executive positions where they would be able to influence issues in their society, this corroborates the findings of Kasomo (2012). At the ward and local government/council levels, the political party officials are mostly men scored $(\mathrm{M}=4.07, \mathrm{SD}=0.86)$ and in Nigeria $(\mathrm{M}=4.13, \mathrm{SD}=1.032)$ indicating that at the grassroots level most of the party officials are men, and women are relegated to the background in spite of their numerical strength in both countries. According to the respondents, the women who are actively involved in the political process are not involved in the making of policy decisions at the 
grass roots level attracted scores of $(\mathrm{M}=2.28, \mathrm{SD}=1.12)$ in Ghana and $(\mathrm{M}=2.42, \mathrm{SD}=1.16)$ in Nigeria, which implies that the women who are active in politics at the grassroots level make input into the policy process in spite of the fact that they are numerically disadvantaged. Cultural factors such as attachment to family and patriarchal nature of the society discourage women from aspiring for key positions where they would be involved in decision making had moderately high scores of $(M=3.96, S D=1.04)$ in Ghana and $(M=3.99, S D=0.95)$ in Nigeria reiterating the fact that there is continual existence of cultural factors that discourage women from aspiring for key decision making positions in the two countries. This finding corroborates earlier studies by Aina (2012), on the factors that impede women participation across Africa.

Table 2:- Poverty Reduction Strategies and Programmes

\begin{tabular}{|c|c|c|c|c|c|c|}
\hline & \multicolumn{3}{|c|}{ GHANA } & \multicolumn{3}{|c|}{ NIGERIA } \\
\hline Statements & M. & SD & $\mathrm{V}$ & $\mathrm{M}$ & SD & $\mathrm{V}$ \\
\hline $\begin{array}{l}\text { Many poverty reduction programmes have been } \\
\text { implemented over the years among the grassroots dwellers }\end{array}$ & 4.15 & 0.808 & 0.652 & 4.25 & 0.666 & 0.443 \\
\hline $\begin{array}{l}\text { The grassroots women are not involved in the designing of } \\
\text { the poverty reduction programmes }\end{array}$ & 3.97 & 0.850 & 0.723 & 3.82 & 1.053 & 1.109 \\
\hline $\begin{array}{l}\text { The poverty reduction programmes are formulated and } \\
\text { implemented according to the dictates of the government in } \\
\text { power }\end{array}$ & 4.25 & 0.609 & 0.370 & 4.45 & 0.556 & 0.310 \\
\hline $\begin{array}{l}\text { The implementation of most of the poverty reduction } \\
\text { programmes have been politicized by the governments that } \\
\text { formulated them }\end{array}$ & 4.34 & 0.484 & 0.234 & 4.32 & 0.489 & 0.239 \\
\hline $\begin{array}{l}\text { Lack of local input in design of poverty reduction } \\
\text { programmes resulted in such policies not addressing the } \\
\text { needs of the grassroots women }\end{array}$ & 4.30 & 0.681 & 0.464 & 4.33 & 0.714 & 0.549 \\
\hline
\end{tabular}

Source: Researchers field survey (2017-2018)

Table 2 above shows that most of the respondents agreed that many poverty reduction programmes had been implemented over the years among the grassroots dwellers on a scale of five had high scores in $\mathrm{Ghana}(\mathrm{M}=4.15$. $\mathrm{SD}=0.81)$ and $(\mathrm{M}=4.25, \mathrm{SD}=0.67)$ in Nigeria, showing that a myriad of poverty reduction of programmes had been implemented among the grassroots populations in the two countries. This corroborates the studies by Angers (2010). Moderately high scores of $(M=3.97, S D=0.85)$ in Ghana and $(M 3.82, S D=1.05)$ in Nigeria on the grassroots women are not involved in the designing of the poverty reduction programmes, show that poverty reduction programmes had been planned and executed without the input of the grassroots women, who those poverty reduction programmes targeted.

High scores in both countries on the poverty reduction programmes are formulated and implemented according to the dictates of the government in power $(\mathrm{M}=4.25, \mathrm{SD}=0.61)$ in Ghana and $(\mathrm{M}=4.45, \mathrm{SD}=0.56)$ in Nigeria show that it is the government in power that determines what poverty reduction programmes to design and implement without input from the grassroots populations. This had also accounted for the inconsistency in poverty reduction programmes in the countries, as different regimes adopt new policies while abandoning those of their predecessors in government.

The implementation of most of the poverty reduction programmes have been politicized by the governments that formulated them attracted high scores of $(M=4.34, S D=0.48)$ in Ghana and $(M=4.32, S D=0.49)$ in Nigeria. These show that rather than focusing on actual poverty reduction in the countries, various governments have used their poverty reduction programmes as tools of political capital. In many instances beneficiaries had been people who have close relationship with key political figures and not necessarily the poor in the various communities.

Lack of local input in design of poverty reduction programmes resulted in such policies not addressing the needs of the grassroots women with high scores of $(\mathrm{M}=4.30, \mathrm{SD}=0.68)$ in Ghana and $(\mathrm{M}=4.33, \mathrm{SD}=0.71)$ in Nigeria, indicate that poverty reduction policies and programmes had missed the expected targets as a result of the fact that the grassroots population did not make input into the designing and formulation of such programmes. This had resulted in disconnect between the people targeted for poverty reduction and the programmes that were implemented as such 
programmes did not address their needs leading to the inability of such programmes to alleviate poverty in the countries.

Hypothesis Results for Ghana

$\mathrm{Ho}_{1}$ : Grassroots women political participation had no significant effect on poverty reduction strategies in Ghana

\begin{tabular}{|l|l|l|l|l|}
\hline Model Summary & R Square & Adjusted R Square & $\begin{array}{l}\text { Std. Error of the } \\
\text { Estimate }\end{array}$ \\
\hline Model & R & .028 & .024 & 2.90277 \\
\hline \multicolumn{2}{|l|}{ a. Predictors: (Constant), GWPP } \\
\hline
\end{tabular}

\section{Coefficients $^{\mathbf{a}}$}

\begin{tabular}{|l|l|l|l|l|l|l|}
\hline \multicolumn{2}{|c|}{ Model } & \multicolumn{2}{|l|}{ Unstandardized Coefficients } & $\begin{array}{l}\text { Standardized } \\
\text { Coefficients }\end{array}$ & \multirow{2}{*}{ Sig. } \\
\cline { 3 - 8 } \multicolumn{2}{c|}{} & B & Std. Error & Beta & & \\
\hline \multirow{2}{*}{1} & (Constant) & 33.501 & 1.661 & & 20.174 & $.000^{\mathrm{a}}$ \\
\cline { 2 - 6 } & GWPP & .147 & .056 & .167 & 2.600 & .010 \\
\hline
\end{tabular}

a. Dependent Variable: PRSAP

The results show that Grassroots women political participation had significant effect on poverty reduction in Ghana $\left(\beta=.167, t(240)=20.174, R^{2}=.028, p<0.05\right)$.

\section{Hypothesis Result for Nigeria}

$\mathrm{Ho}_{2}$ : Grassroots women political participation had significant effect on poverty reduction strategies in Nigeria

\begin{tabular}{|l|l|l|l|l|}
\hline \multicolumn{5}{|l|}{ Model Summary } \\
\hline Model & R & R Square & Adjusted R Square & Std. Error of the Estimate \\
\hline 1 & $.033^{\mathrm{a}}$ & .001 & -.004 & 2.30323 \\
\hline a. Predictors: (Constant), GWPP
\end{tabular}

\begin{tabular}{|c|c|c|c|c|c|c|}
\hline \multicolumn{7}{|c|}{ Coefficients $^{\mathrm{a}}$} \\
\hline \multirow{2}{*}{\multicolumn{2}{|c|}{ Model }} & \multicolumn{2}{|c|}{ Unstandardized Coefficients } & Standardized & \multirow[t]{2}{*}{$\mathrm{t}$} & \multirow[t]{2}{*}{ Sig. } \\
\hline & & $\mathrm{B}$ & Std. Error & Beta & & \\
\hline \multirow[t]{2}{*}{1} & (Constant) & 37.015 & 1.647 & & 22.478 & $.000^{\mathrm{a}}$ \\
\hline & GWPP & .024 & .052 & .033 & .468 & .640 \\
\hline
\end{tabular}

The results show that Grassroots women political participation had significant effect on poverty reduction in Nigeria $\left(\beta=.033, t(197)=22.478, R^{2}=0.01, p<0.05\right)$.

This shows that grassroots women political participation had a significant effect on poverty reduction in both Ghana and Nigeria. This is an indication that both countries have similar characteristics in terms of design, formulation and implementation of poverty reduction programmes targeting grassroots women. This finding corroborates the earlier study by Kasomo (2012) which stated that the low number of women involved in the decision making process has negative effect on the policy outputs, as the interests of the women are not adequately catered for by the predominantly male decision makers. Ghana and Nigeria are yet to integrate the propositions of the intersectionality theorists in their decision making processes in terms of poverty reduction programme as the unique factors that affect women are not being considered by the male dominated decision making apparatus in the formulation and implementation of poverty reduction strategies. This may be implicated in the high level of poverty among grassroots women in the two countries who are although engaged in agricultural production are limited in their capacities by unfavourable landownership laws.

There is need for more grassroots women to be involved in the designing and implementing of poverty reduction programmes that target their population for such programmes to be successful. The politicization of the poverty reduction programmes by various governments without input from the target population of such programmes would always result in the failure of such programmes. Electing and appointing more women to key decision making 
positions in both countries would ensure that the women are able to make the necessary inputs into formulation of the poverty reduction programmes thereby guaranteeing the success of such programmes thereby achieving the eradication of poverty in the two countries.

\section{The Way Forward}

There is need to get women into the decision making roles at the grassroots level, this would ensure that issues that affect them are adequately addressed. Since would ensure that poverty reduction strategies are placed at the front burner of the policy process.

There is need to make national laws as well as state laws that would take care of existing practices that are outrightly anti-women such as the land ownership rights and inheritance rights especially in parts of the South where women are not entitled to inheriting landed property.

There is need for very intensive sensitization of women for them to become active in politics. All the fabricated stereo-types which some women have bought into need to be dismantled to facilitate the active participation of more women at the gladiatorial levels.

There is need for adoption of gender quotas. Specific quotas should be allocated to women such that they do not compete against men to fill those quotas as is applicable in Rwanda. This would facilitate the increase in the number of women who would be elected to decision making and legislative positions.

\section{Conclusion:-}

The level of grassroots women political participation at gladiatorial or decision making roles in Ghana and Nigeria is not proportional to their population. Even at the grassroots level where a large number of women are very active in politics the majority of the officials are male, which means that the women are marginalized. Most of the time the position reserved for them is that of Women Leader.

Larger number of the poverty stricken at the grassroots level in Ghana and Nigeria are women who live on subsistence farming but are denied ownership of land by obnoxious land right laws that are outrightly anti-women. This had denied some women access to land for economic purposes making it difficult for them to overcome poverty.

There are more grassroots women who are poor than the male as result of unfavorable land ownership laws in both countries, among other factors. These anti women laws have persisted because of the fact that the decision maker and law makers in both countries are predominantly male are not positively minded towards changing the status quo. This had negatively impacted the grassroots women in both countries.

\section{References:-}

1. Anger, B. (2010). Poverty Eradication, Millennium Development Goals and Sustainable Development in Nigeria. Journal of Sustainable Development. Vol. 3, No. 4; December 2010, pp 138-144.

2. Boateng, G. O, Boateng, A. A., Bampoe, H. S. (2015). Microfinance and Poverty Reduction in Ghana: Evidence from Policy Beneficiaries. Review of Business and Finance Studies, Volume 6, Number 1, 2015, pp $99-108$.

3. Cole, S. (2011). Increasing Women's Political Participation in Liberia Challenges and Potential Lessons from India, Rwanda and South Africa. Washington DC: International Foundation for Electoral Systems (IFES).

4. Cooper, B. (2016). Intersectionality. In Disch, L. and Hawskesworth, M. (eds). The Oxford Handbook of Feminist Theory. (pp 385 - 406). New York: Oxford University Press.

5. Crenshaw, K. W. (1991). Mapping the Margins: Intersectionality, Identity Politics, and violence against women of color. Stanford Law Review, 43 (6), pp 1241 - 1299.

6. Crenshaw, K. W. (1989). Demarginalizing the Intersection of Race and Sex: A Black Feminist Critique of Antidiscrimination Doctrine, Feminist theory, and Antiracist Politics. University of Chicago Forum 1989, pp. $139-167$.

7. Domfeh, K. A., Ahenkan, A. and BawoleIs, J. N. (2012). Sustainable development achievable in Ghana? An analysis of Ghana's development policy achievements and challenges. Int. Journal Environment and Sustainable Development, Vol. 11, No. 3, 2012, pp 304-317. 
8. Fapohunda, T. M. (2012). Gender and Development: Challenges to Women Involvement in Nigeria's Development. International Journal of Academic Research in Business and Social Sciences, June 2012, Vol. 2, No. 6, pp. 14-28.

9. Hancock, A. M (2007). When multiplication doesn't equal quick addition. Perspectives on Politics 5 (1): $63-79$.

10. Handley, G., Higgins K., Sharma, B., Bird K. and Cammack, D. (2009) Poverty and poverty reduction in subSaharan Africa: An overview of the issues. Overseas Development Institute Working paper 299. London:Overseas Development Institute.

11. Huq, S. M. S. (2016). Women's Participation in Local Government: A Tool For Sustainable Development of Bangladesh. European Journal of Business and Social Sciences, Vol. 4, No. 11, February 2016.Pp. 169 - 183. Available online URL: http://www.ejbss.com/recent.aspx-/

12. International Monetary Fund (IMF) (2012). Ghana: Poverty Reduction Strategy Paper. IMF Country Report No. 12/203. Washington DC: International Monetary Fund.

13. Isshaku, A. M. (2012). Enhancing Grassroot Participation in Local Governance: the role of sub-district structures (area and urban councils) in Wa Municipality and Wa East District of the Upper West Region. Being a thesis submitted to the Department of Planning, Kwame Nkrumah University of Science and Technology, Kumasi. In partial fulfillment of the requirements for the degree of Master of Science in Development Policy and Planning. Available online at ir.knust.edu.gh/...FINAL\%2BTHEIS\%2B2012\%2B$\% 2 C \% 2 B A D A M S \% 2 B M A H A M .$.

14. Kasomo, D. (2012). Factors Affecting Women Participation in Electoral Politics in Africa. International Journal of Psychology and Behavioral Sciences 2012, 2(3): 57-63 DOI: $\quad$ 10.5923/j.ijpbs.20120203.01

15. Kessey, K. D. (2013). Global poverty reduction policy and implementation strategies at local level, integrated planning options and challenges in a developing country, Ghana. Merit Research Journal of Art, Social Science and Humanities Vol. 1(6) pp. 076-085, October, 2013. Available online http://www.meritresearchjournals.org/assh/index.htm

16. McCall, L. (2005). The complexity of intersectionality. Signs 30(3): 1771-1800.

17. National Democratic Institute (2010). Democracy and the Challenge for Change: A Guide to Increasing Women's Political Participation. Washington DC: National Democratic Institute.

18. National Economic Empowerment and Development Strategy Document. (2004). National Planning Commission, Abuja.

19. Odeny, M. (2013). Improving Access to Land and strengthening Women's land rights in Africa. Paper presented at the Annual World Bank Conference On Land And Poverty" The World Bank - Washington DC, April 811,2013

20. Okafor, E. and Akokuwebe, M. E. (2015). Women and Leadership in Nigeria: Challenges and Prospects. Developing Country Studies.Vol 5, No 4, pp. 1 - 10 . Available from: https://www.researchgate.net/publication/292141382_Women_and_Leadership_in_Nigeria_Challenges_and_Pr ospects.

21. Osei-Kufuor, P. and Koomson, F. (2014). Reducing poverty through community participation: The case of the National Poverty Reduction Program in the Dangme-West district of Ghana. Development and Sustainability, Volume 3 Number 8 (2014), Pages 1611-1628

22. Pogoson, A. I. (2015). The Face of 'Eve' in Nigerian Politics: Laying claims to the public Space. In Momoh, A. (ed.) Democracy and Socio-economic Issues in Nigeria. (Pp 68 - 89). Abuja: Friedrich Ebert Stiftung \& Society for International Relations Awareness.

23. Walby, S., Armstrong, J. and Strid, S. (2012). Intersectionality: Multiple Inequalities in Social Theory. Sociology 46(2) 224 -240. DOI: 10.1177/0038038511416164. 